\title{
CONTROLLED POLLINATIONS REVEAL SELF-INCOMPATIBILITY AND INBREEDING DEPRESSION IN THE NUTRITIONALLY IMPORTANT PARKLAND TREE, PARKIA BIGLOBOSA, IN BURKINA FASO
}

\author{
Kristin Marie Lassena, Erik Dahl Kjæra, Moussa Ouédraogo ${ }^{\mathrm{b}}$, Yoko Luise Dupontc, Lene Rostgaard Nielsen ${ }^{\mathrm{a}}$ \\ ${ }^{a}$ Department of Geosciences and Natural Resource Management, Faculty of Science, University of Copenhagen, Rolighedsvej 23, 1958 \\ Frederiksberg C, Denmark \\ ${ }^{b}$ Centre National de Semences Forestières, Route de Kaya, 01 BP 2682 Ouagadougou, Burkina Faso \\ 'Department of Bioscience, Aarhus University, Vejlsøvej 25, 8600 Silkeborg, Denmark
}

\begin{abstract}
The socioeconomically important fruit tree Parkia biglobosa is becoming less abundant in the West African savannah, possibly due to poor regeneration. This decline can be self-enforcing if lower densities of fertile trees result in increasing self-pollination followed by increased abortion rates or poor regeneration due to inbreeding depression. Hence, we have studied the reproductive success and seedling viability of P. biglobosa after controlled selfand cross-pollination based on a full diallel crossing design with eight trees. Controlled cross-pollination tripled the pod set compared to open-pollinated capitula, suggesting that fruiting of P. biglobosa trees in the study area is already seriously pollen limited. Self-pollination and specific pairs of trees resulted in very few pods, suggesting a high level of self-incompatibility. Cross-pollination resulted in larger pods with more and heavier seeds than self-pollinated pods. The total amount of sugar in the fruit pulp was correlated with both the number of healthy and total seeds per pod. Growth rate of self-pollinated seedlings was lower than the cross-pollinated ones, suggesting significant inbreeding depression. Because the wild fruit trees play an important role in human nutrition, these results give rise to serious concerns. We recommend that future studies investigate how the level of cross-pollination can be increased and how the regeneration of $P$. biglobosa, whether natural or planted, can be improved.
\end{abstract}

Keywords: Controlled pollination; Fruit quality; Inbreeding depression; Pollen limitation; Self-incompatibility

\section{INTRODUCTION}

The majority of tropical tree species rely on animals for pollination (Ollerton et al. 20I I), and many possess a system of self-incompatibility (Bawa et al. 1985; Ward et al. 2005). The high dependency on animal pollinators in the tropics (Ollerton et al. 20II), combined with pollination deficit due to historical decline of wild pollinators (e.g. Goulson et al. 2015) and limited alternative options for cross-pollination, may decrease fruit production and quality of important crop trees. In addition, anthropogenic impacts, such as farming (monoculture, pesticides), landscape fragmentation, and climate change are likely to reduce abundance and species diversity of pollinators (Kennedy et al. 2013). Understanding mechanisms of pollination and optimising fruit production in tropical fruit trees are crucial, given that many livelihoods depend on crop yield from animal-pollinated tropical trees.

Local decline of pollinators and/or increased distances between conspecific trees can reduce seed set due to pollen limitation, if fruit and seed set are limited by the supply of compatible pollen, rather than resource availability (Ashman et al. 2004; Knight et al. 2005; Aizen \& Harder 2007).

Received 7 March 2018, accepted 17 October 2018

*Corresponding author: kristin_lassen@yahoo.dk
Another potential consequence is increased selfing, which may decrease fruit production, and reduce the fitness of seedlings due to inbreeding depression (Husband \& Schemske 1996). Hence, we expect a decrease in reproductive success, combined with reduction of seedling fitness when conspecific trees are more widely spaced in a disturbed landscape.

Parkia biglobosa (Jacq.) R. Br. ex G. Don (Fabaceae: Mimosoideae), is a West African parkland tree with high nutritional importance for the rural people due to its sweet fruit pulp and seeds with high protein content (Uwaegbute 1996; Hall et al. 1997). In Burkina Faso, pods from $P$. biglobosa are an important food source (Lykke et al. 2002), especially during periods of food scarcity (Nyadanu et al. 2017). Due to over-exploitation (Gaisberger et al. 2017), low regeneration (Ræbild et al. 2012), and reduced annual rainfalls (Maranz 2009; Funk et al. 2012), there is a high risk of seriously decreasing tree densities (Gaisberger et al. 2017) as already witnessed by the local population (Lykke et al. 2002). This may increase selfing (Lassen et al. 2017), but the potential effects of increased self-pollination on seedling growth and nutritional content of the fruits of P. biglobosa are unknown. Related species possess a self-incompatibility system (Hinata et al. 1993), and hence increased selfing is expected to reduce seed set. Studies of other plant species have documented positive correlations between seed number and fruit traits including fruit weight, size, and oil content (Hopping 1976; Roldán Serrano \& Guerra-Sanz 2006; Abrol 
20I2). Thus, increased self-pollination, by causing reduced seed number, may also reduce the nutritional value of $P$. biglobosa fruits.

To understand productivity of this important crop tree species, it is important to determine if P. biglobosa is pollen limited, and how increased levels of self-pollination will affect fruit and seed set, nutrition contents and seedling fitness of this species. We addressed these questions by performing controlled self- and cross-pollinations of P. biglobosa capitula in order to compare I) the reproductive success of selfed, crossed, and open-pollinated capitula, 2) the carbon and nitrogen contents of seeds and sugar content of fruit pulp from selfed and outcrossed pods, and 3) the germination percentage and seedling vigour of selfed and outcrossed seeds. We discuss the probability of $P$. biglobosa experiencing pollen limitation, self-incompatibility and inbreeding depression.

\section{MATERIALS AND METHODS}

\section{Plant species}

Parkia biglobosa is pollinated mainly by bees and bats (Baker \& Harris 1957; Hopkins I983; Ouédraogo I995; Lassen et al. 2012; Lassen et al. 2017). It is predominantly outcrossing (Ouédraogo 1995; Sina 2006), although Lassen et al. (2017) found that selfing can occur in areas with low tree density. Parkia biglobosa flowers for around four weeks in the dry season in Burkina Faso from January to April, depending on latitude, and with year to year variation (pers. obs.).

Flowers are grouped in ball-shaped capitula with around 2,200 tiny bright red flowers packed closely on a bulbous receptacle hanging on a long peduncle (Hopkins 1983). Nectar is produced by sterile flowers close to the peduncle and accumulates in a nectar ring (Hopkins 1983). At the study site, buds opened during the afternoon. The capitula started producing nectar around I8:45 h (local time, UTC $+0 \mathrm{~h}$ ) and shedding pollen around 19:30 h (pers. obs.). Each tiny flower has ten anthers and one style. Parkia biglobosa is andromonoecious, and the functionally male capitula have styles, which fail to elongate (Hopkins 198I). Pollen is shed in polyads with 32 pollen grains (pers. obs.) clumped together. The cup-shaped stigma can hold only one polyad; therefore all seeds per pod are full siblings (Lassen et al. 20I4). According to our observations, based on $N=I 5$ ovaries distributed on three trees in Burkina Faso, the ovary of a hermaphroditic capitulum contained a mean of 23 ovules (SE $=0.63$, min-max: 16-29). The hermaphroditic capitula are protandrous (Ouédraogo 1995) and the female phase begins around 23:00-24:00 $\mathrm{h}$ when the stigmas have extended to reach the same level or above that of the anthers (pers. obs.). Furthermore, flowering within a capitulum is highly synchronized. Each capitulum blooms one night and during the morning both hermaphroditic and functionally male capitula start to wilt (pers. obs.). In the present study, each capitulum is treated as one unit.

One week after pollination and fertilisation, tiny green pods are visible, and after around two months the indehiscent, brown pods are mature (pers. obs.). Even though each hermaphroditic flower has the potential of producing a pod, only a few pods per capitulum develop (Hopkins I984).

\section{Study site}

The present study took place in the village Pinyiri (syn. Kacheli) (I I ${ }^{\circ} 4^{\prime} 34.89^{\prime \prime} \mathrm{N}, \mathrm{I}^{\circ} 8^{\prime} \mathrm{I} .73^{\prime \prime} \mathrm{W}$ ), eight km north of Pô, Nahouri province. The site is within the Sudanian climatic zone with a unimodal rainy season and an average precipitation (I98I-20I0) of 900-I,000 mm (Sanfo 20I2). In $201 \mathrm{I}$, preceding the fruiting season of P. biglobosa in 2012, the annual precipitation in Pô was $927 \mathrm{~mm}$ (Météo 2015).

\section{Controlled pollination experiment}

Prior to the experiment, swollen buds (expected to open the following night) were covered with cheesecloth with an inner band of chicken wire to keep the nettings from touching the flowers. We used inflorescences from the lowest part of the tree crown, which could be reached from a ladder. In the experiment, only the most apical bud within the compound inflorescence was used. During 8-I8 March 2012, the crossing experiment was carried out as a diallelic cross (i.e. all trees were crossed with each other) of eight trees (mean DBH $=\mathrm{I} .4 \mathrm{~m}, \mathrm{SD}=0.8 \mathrm{I}$ ), although one of the trees was not used as a pollen donor. Each treatment was replicated nine times per tree.

\section{Treatments:}

- $\quad$ Open $=$ open-pollinated capitula $($ control, $N=72)$

- $\quad$ Self $=$ self-pollinated capitula $(N=72)$

- $\quad$ Cross $=$ cross-pollinated capitula $(N=423)$

- $\quad$ 'Both' = half of a capitulum was pollinated with self-pollen and the other half with cross-pollen (only on six trees due to lack of capitula, $N=54$ )

Prior to the pollination treatments, we checked the sex (hermaphroditic or functionally male) of the flowers on each receiving capitulum, since only hermaphroditic capitula can develop pods. When in doubt, we measured the distance between stigmas and anthers, as this difference was suspected to influence the functional sex of the capitulum, due to the probability of the many densely packed anthers acting as a carpet keeping pollen away from the shorter stigmas. The dividing line between hermaphroditic and functionally male capitula was unknown at the time we carried out the controlled pollinations. Hence, these were carried out regardless of the assigned sex, from midnight until early morning (03-04 h) using capitula directly as pollen brushes by dabbing the donor capitula on the receiving capitula, which were previously protected by bags. No flowers were emasculated due to the high number of anthers per capitulum. To standardise the dose of pollen, one donor capitulum was used on three receiving capitula (I:3) for the treatments of self- and cross-pollinations (approximately one third of the donor on each of the receiving capitulum). To study the effect of self- and cross-pollination under identical conditions, we applied self and cross-pollen to flowers on the same capitulum (but not the same flowers). We refer to this treatment as 
'both', and for this treatment we used two donor capitula (self and cross) for two receiving capitula (half self and half cross on each capitulum) (I:I). Half of the peduncle was marked with a black marker (for the cross-pollination) and we performed the two kinds of pollination by eye. After pollination, the capitula were re-bagged. The trees were visited daily for five weeks; dropped capitula were collected and examined for sex (hermaphroditic or functionally male) and signs of developing pods and/or predation.

After harvest, pods were counted and weighed. Their lengths were measured as the mean of each side of the pod, excluding the pedicel. We did not count the seeds of these pods (see below).

\section{DNA extraction and genotyping}

To assess the level of self-pollination (on purely selfpollinated capitula and on 'both' capitula), we extracted DNA, genotyped seeds $(N=\mathrm{I} 42)$ and compared their genotypes with the genotype of the mother trees. Likewise, genotypes of the eight experimental trees were compared to genotypes of a sub-sample of pods, to test if the cross had been performed correctly. DNA was extracted directly from dehulled seed; endosperm is absent because the cotyledons provide resources to the embryo (Hopkins I983). DNA extraction used the DNeasy 96 Plant Kit (QIAGEN, Hombrechtikon, Switzerland), following the manufacturer's protocol. The genotyping was based on ten microsatellite primer pairs developed for P. biglobosa (Lassen et al. 2014) with PCR reactions and fragment analysis following Lassen et al. (2017).

\section{Comparison of self- and cross-pollinated pods}

The self-pollinated capitula in the controlled pollination experiment yielded extremely few pods. Thus, in order to compare the quality of seeds in P. biglobosa after self- and cross-pollination we assessed the quality from 48 pods obtained from a previous experiment from the same study site (Lassen et al. 2017). These pods were collected from eleven trees and were randomly selected, although the selection was balanced with an equal number of pods per tree being selfand cross-pollinated. Seeds were categorised as 'healthy', 'eaten' (hole in the husk and/or seed remains due to predation by parrots and/or worms), 'aborted' (weight $<0.05 \mathrm{~g}$ and/or with a flat shape), 'missing' (empty cavity in the pulp), and from these four numbers a total number of seeds was established.

\section{Moisture, carbon and nitrogen content of seeds}

One seed from each of 48 pods (24 selfed and 24 outcrossed) was analysed for moisture, carbon and nitrogen content. The seeds were weighed with and without testa, placed in open $2 \mathrm{ml}$ Eppendorf tubes and dried at $65^{\circ} \mathrm{C}$ for three days until stable weight. Moisture content of seeds without testa was calculated as fresh weight minus dry weight, divided by fresh weight and multiplied by $\mathrm{IOO}(\%)$. Then the dehulled seeds were ground in a mortar and weighed into tin capsules with $5 \mathrm{mg}$ in each sample. Total carbon (C) and nitrogen $(\mathrm{N})$ content were measured using the Dumas principle: samples were combusted at $1,850^{\circ} \mathrm{C}$ on a FLASH 2000 NC Analyzer (Thermo Scientific) according to the manufacturer's manual. To calibrate the measurements, we used a standard ('spruce needles' Forest Foliar Coordinating Centre, FFCC), and two reference samples ('maple leaves' FFCC, run twice, and 'corn gluten organic' Sercon, run for every nine samples of $P$. biglobosa). The FLASH 2000 Analyzer is comparable with the Kjeldahl method (Krotz \& Giazzi 2014).

We have converted the amount of nitrogen $(\mathrm{N})$ to crude protein by multiplying $\mathrm{N}$ with the commonly used factor 6.25 (AOAC 1990), although Ezeagu et al. (2002) found a lower nitrogen-to-protein conversion factor on 4.97 for Fabaceae seeds (mean for ten species) and Yeoh \& Wee (1994) found an even lower conversion factor on 4.23 for leaves of Parkia timoriana (DC.) Merr. (syn. P. javanica).

\section{Pod pulp analysis}

We analysed the sugar content in the pulp of the same pods as above, except for two self-pollinated pods, which had no pulp (i.e. 22 self- and 24 cross-pollinated pods were used in this analysis). We kept the pulp from each pod separately. The pulp was dried $\left(103^{\circ} \mathrm{C}\right.$ for $3 \mathrm{~h}$ ), ground and sifted, and two sub-samples of $100 \mathrm{mg}$ per pod were used. The soluble sugars were extracted and analysed by HPLC according to the method described by Liu et al. (2004).

Germination rate and seedling vigour of selfed and crossed seeds

In order to compare seed viability under optimal conditions, we tested the germination by using healthylooking seeds from the 24 self-pollinated pods ( 90 seeds) and 24 cross-pollinated pods (I63 seeds) and assessed the seedling vigour by growth and dry weight. Each seed was weighed and scarified because of the hard seed coat (testa), which must be broken before the seeds can germinate (Etejere et al. 1982). The seeds were germinated in plastic boxes in a growth chamber in a $25^{\circ} \mathrm{C}$ day and night, and $\mathrm{I} 2 \mathrm{~h}$ light/darkness regime. We defined the seeds as germinated when the radicle protruded for $3 \mathrm{~mm}$, and we monitored the seed germination daily.

On the $19^{\text {th }}$ day after sowing, seedlings were weighed and planted individually in pots $(\varnothing=\mathrm{I} 3 \mathrm{~cm})$ with planting peat soil. The pots were placed randomly in a greenhouse at $28^{\circ} \mathrm{C}$ day and $20^{\circ} \mathrm{C}$ night and with a $12 \mathrm{~h}$ light/darkness regime from 08:00 h (local time, UTC + I h). The seedlings were watered daily with demineralised water without fertiliser for the first 2 months, and thereafter with fertiliser. Plant height (from soil level to top of main stem, or to the highest stem in case of more stems), stem diameter (measured with an electronic caliper) and number of pinnae (i.e. primary division of a bipinnate compound leaf) were measured on five occasions (43, 76, I04, I44, and 222 days after sowing). At the last measuring, we included fresh weight of the seedlings before drying them at $80^{\circ} \mathrm{C}$ (Osonubi \& Fasehun 1987). After 24 hours (until stable weight), we recorded dry weight of the entire plant, shoots (stem plus leaves) only, and roots only, in order to calculate the shoot:root ratio.

\section{Data analysis}

In the controlled pollination experiment, reproductive success was evaluated as I) numbers of immature pods 
(reflecting the success of pollination) and mature pods (additionally reflecting available resources by the mother-tree) per hermaphroditic capitulum and 2) weight and length of these pods. Analysis of variance was performed based on average values per treatment and tree applying the statistical SAS software v.9.4 (SAS Institute 201 I). The mean number of pods (immature and mature) per hermaphroditic capitulum included capitula without any pods. When testing differences between treatments for the controlled pollination experiment, we used the general linear model as implemented in the GLM procedure:

\section{I. $Y_{g h}=$ Treatment $_{g}+$ Mother-tree $h+\varepsilon_{g h}$}

where $Y_{g h}$ is the response variable, treatment $g=$ (open, self, cross, 'both'), and mother-tree $h=1 \ldots 8$. Treatment ${ }_{g}$ was considered a fixed effect, whereas Mother-tree $h$ was considered a random effect with residual $\varepsilon_{g h}$ assumed independent and $\mathrm{N}\left(0, \sigma_{e}{ }^{2}\right)$. We assessed and accepted the model assumptions by visual inspection of the residuals.

For testing differences among pairs of pollen donors (i.e. male parent) and mother-trees (i.e. female parent), we analysed number of pods per single capitulum (not averaged per tree), using the general linear model as implemented in the GLM procedure:

2. $Y_{i j}=$ Pollen donor $_{i}+$ Mother-tree $_{j}+$ Pollen donor $_{i}^{*}$ Mother-tree $_{j}+\mathcal{E}_{i j}$

where $Y_{i j}$ is the response variable (log transformed), pollen donor $i=$ (TI0, TI4, T22, T76, T90, T92, and T93), mother-tree $j=\mathrm{I} \ldots 8$, and pollen donor $_{i}$ mother-tree $_{j}=$ the interaction between the pollen donor and the mother-tree. All effects were considered fixed with residual $\mathcal{E}_{i j}$ assumed independent and $\mathrm{N}\left(0, \sigma_{e}{ }^{2}\right)$. We assessed and accepted the model assumptions by visual inspection of the residuals.

When testing differences between self- and crosspollination for several parameters related to plant fitness, the results were averaged per type of pollination and tree, and we used a similar general linear model as above:

$$
\text { 3. } Y_{k l}=\text { Pollination type } k+\text { Mother-tree } I+\varepsilon_{k l}
$$

where $Y_{k l}$ is the response variable, pollination type $k=$ (self, cross), and mother-tree $l=I$ I...II. Pollination type $k$ was considered a fixed effect, whereas Mother-tree $/$ was considered a random effect with residual $\varepsilon_{k l}$ assumed independent and $\mathrm{N}\left(0, \sigma_{e}{ }^{2}\right)$. Again, we assessed and accepted the model assumptions by visual inspection of the residuals.

When testing the difference between carbon and nitrogen contents of selfed versus outcrossed seeds, we used the following general linear model: $+\varepsilon_{k l m}$

4. $Y_{k l m}=$ Pollination type $k+$ Mother-tree $t+$ Seed weight ${ }_{m}$

where $Y_{k l m}$ is the response variable, pollination type $k=$ (self, cross), mother-tree $l=\mathrm{I}$...II, and seed weight included as covariate. Seed weight varied from 0.082I - 0.2733 g per seed. Pollination type $k$ was considered a fixed effect, whereas Mother-tree/ was considered a random effect with residual $\varepsilon_{k l m}$ assumed independent and $\mathrm{N}\left(0, \sigma_{c}^{2}\right)$. Again, we assessed and accepted the model assumptions by visual inspection of the residuals.

We used Fisher's exact test (as implemented in SAS procedure FREQ) to test differences between self- and crosspollination for number of germination seeds and surviving seedlings.

The relationship between number of seeds per pod and sugar content in fruit pulp was analysed by calculation of Pearson correlation coefficients (using SAS procedure CORR).

\section{RESULTS}

\section{Assessment of the diallel crossing experiment}

In the controlled pollination experiment, 45I capitula were hermaphroditic, I39 capitula were functionally male, and 45 capitula were 'mixed' (i.e. containing both hermaphroditic and functionally male flowers in different ratios). Of capitula with hermaphroditic flowers, $83 \%$ developed pods.

The measurement of distances between stigmas and anthers of the capitula ( $N=245$ capitula) coupled with the reproductive success (setting fruit or not) revealed that capitula having anthers protruding $>5 \mathrm{~mm}$ longer than stigmas were typically functionally male (9I\%). Hence, this measure could be used as a rule of thumb.

Of the four pollination treatments (open, self, cross, and 'both'), self-pollination led to a significantly lower proportion of capitula with at least one immature pod (100\%, 19\%, $96 \%, 97 \%$, respectively). In addition, the mature pod set also differed, and the experiment yielded 2,643 pods for the purely cross-pollinated capitula ( 423 pollinated capitula) and only 2 pods for the purely self-pollinated capitula ( 72 pollinated capitula). Genotyping of a subset of pods confirmed that cross-pollinated pods indeed were results of cross-pollinations while a few matured 'self-pollinated' pods, turned out to be cross-pollinated, probably due to small amounts of 'carryover' pollen. For treatment 'both', in which 502 pods were matured, no pods developed in the self-pollinated halves of the capitula and the subset of genotyped pods showed no self-pollination $(N=\mathrm{I} 33)$.

\section{Effects of pairs of trees and pollen doses on fruit set}

In the controlled cross-pollination treatments, we found highly significant effects of both mother-trees (female parent, $F_{(7,231)}=9.1, P<0.001$ ) and pollen donors (male parent, $F_{(6,231)}=4.7, P<0.001$ ) on the number of immature pods per hermaphroditic capitulum. However, the number of mature pods was only significantly affected by the mother-trees $\left(F_{(7,199)}=13.5, P<0.001\right)$. Two trees (PI4 and P22) were equally good as mother-trees and pollen donors, whereas three trees had highest reproductive success as mother-trees (i.e. producing many pods, P76, P92, and P93) and two trees were best as pollen donors (i.e. fathering many pods, TIO and T90) (Tab. I and 2).

Interactions between mother-trees and pollen donors were highly significant for both immature $\left(F_{(34,231)}=3.4, P<\right.$ $0.00 \mathrm{I})$ and mature pods $\left(F_{(34,199)}=3.4, P<0.00 \mathrm{I}\right)$, i.e. fruit set depended on the combination of mother-trees and pollen 
TABLE I. Mean number ( \pm SE) of immature pods per hermaphroditic capitulum (i.e. small pods before maturation) of Parkia biglobosa (incl. capitula without pods). Self-pollination (grey colour) is shown in the last row. Tree P33 did not give pollen to the other trees.

\begin{tabular}{|c|c|c|c|c|c|c|c|c|c|c|}
\hline \multicolumn{11}{|c|}{ Female parent (i.e. mother-tree) } \\
\hline \multicolumn{2}{|c|}{ Treatment } & PIO & PI4 & P22 & P33 & P76 & P90 & P92 & P93 & $\begin{array}{c}\text { Across } \\
\text { trees }\end{array}$ \\
\hline \multirow{11}{*}{ 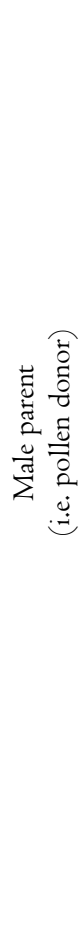 } & Open $^{a}$ & $\begin{array}{c}4 . \mathrm{I} \\
(4.80)\end{array}$ & $\begin{array}{c}5.6 \\
(4.52)\end{array}$ & $\begin{array}{c}\mathrm{I} .3 \\
(4.52)\end{array}$ & $\begin{array}{c}2.8 \\
(4.52)\end{array}$ & $\begin{array}{c}7.1 \\
(4.52)\end{array}$ & $\begin{array}{c}2.9 \\
(4.52)\end{array}$ & $\begin{array}{c}2.8 \\
(4.52)\end{array}$ & $\begin{array}{c}4.3 \\
(4.52)\end{array}$ & $\begin{array}{c}3.9 \\
(0.4 \mathrm{I})\end{array}$ \\
\hline & TIO & - & $\begin{array}{c}42.5 \\
(5.54)\end{array}$ & $\begin{array}{c}41.7 \\
(7.83)\end{array}$ & $\begin{array}{c}5.0 \\
(7.83)\end{array}$ & $\begin{array}{c}50.0 \\
(4.52)\end{array}$ & $\begin{array}{c}10.3 \\
(7.83)\end{array}$ & $\begin{array}{c}23.9 \\
(5.13)\end{array}$ & $\begin{array}{c}61.6 \\
(4.80)\end{array}$ & $\begin{array}{c}39.4 \\
(4.74)\end{array}$ \\
\hline & TI4 & $\begin{array}{c}\text { I5.5 } \\
(4.80)\end{array}$ & - & $\begin{array}{c}\text { I5.8 } \\
(4.52)\end{array}$ & $\begin{array}{c}9.6 \\
(4.80)\end{array}$ & $\begin{array}{c}31 . I \\
(4.52)\end{array}$ & $\begin{array}{c}1.0 \\
(6.07)\end{array}$ & $\begin{array}{c}23.5 \\
(5.54)\end{array}$ & $\begin{array}{c}22.6 \\
(5.13)\end{array}$ & $\begin{array}{c}17.8 \\
(2.08)\end{array}$ \\
\hline & $\mathrm{T} 22$ & $\begin{array}{c}26.8 \\
(5.54)\end{array}$ & $\begin{array}{c}17.3 \\
(5.13)\end{array}$ & - & $\begin{array}{c}18.8 \\
(6.07)\end{array}$ & $\begin{array}{c}26 . I \\
(4.52)\end{array}$ & $\begin{array}{c}7.4 \\
(5.13)\end{array}$ & $\begin{array}{c}9.5 \\
(5.54)\end{array}$ & $\begin{array}{c}26.5 \\
(4.80)\end{array}$ & $\begin{array}{c}19.4 \\
(2.23)\end{array}$ \\
\hline & $\mathrm{T} 33$ & na & na & na & - & na & $\mathrm{Na}$ & na & na & na \\
\hline & $\mathrm{T} 76$ & $\begin{array}{c}10.7 \\
(5.13)\end{array}$ & $\begin{array}{c}\text { I5.3 } \\
(5.54)\end{array}$ & $\begin{array}{c}\text { I5.4 } \\
(4.80)\end{array}$ & $n a^{d}$ & - & $\begin{array}{c}9.5 \\
(5.54)\end{array}$ & $\begin{array}{c}1.0 \\
(7.83)\end{array}$ & $\begin{array}{c}27.5 \\
(5.54)\end{array}$ & $\begin{array}{c}\mathrm{I} 4.3 \\
(\mathrm{I} .70)\end{array}$ \\
\hline & T90 & $\begin{array}{c}\mathrm{I} 2.4 \\
(6.07)\end{array}$ & $\begin{array}{c}\text { I.I } \\
(5.13)\end{array}$ & $\begin{array}{c}22.0 \\
(6.07)\end{array}$ & $\begin{array}{c}\text { I2.0 } \\
(4.80)\end{array}$ & $\begin{array}{c}39.0 \\
(4.52)\end{array}$ & - & $\begin{array}{c}42.5 \\
(6.78)\end{array}$ & $\begin{array}{c}20.3 \\
(7.83)\end{array}$ & $\begin{array}{c}20.9 \\
(3.11)\end{array}$ \\
\hline & T92 & $\begin{array}{c}18.2 \\
(5.54)\end{array}$ & $\begin{array}{c}23.7 \\
(5.54)\end{array}$ & $\begin{array}{c}\text { I4.2 } \\
(6.07)\end{array}$ & $\begin{array}{c}18.0 \\
(\mathrm{I} 3.57)\end{array}$ & $\begin{array}{c}\text { II.6 } \\
\text { (5.13) }\end{array}$ & $\begin{array}{c}8.5 \\
(5.54)\end{array}$ & - & $\begin{array}{c}25.8 \\
(6.78)\end{array}$ & $\begin{array}{c}16.4 \\
(1.97)\end{array}$ \\
\hline & T93 & $\begin{array}{c}26.5 \\
(5.54)\end{array}$ & $\begin{array}{c}25.8 \\
(4.52)\end{array}$ & $\begin{array}{c}9.0 \\
(6.07)\end{array}$ & $\begin{array}{c}7.7 \\
(7.83)\end{array}$ & $\begin{array}{c}23 . I \\
(4.52)\end{array}$ & $\begin{array}{c}\text { I4.6 } \\
(5.13)\end{array}$ & $\begin{array}{c}45.5 \\
(9.59)\end{array}$ & - & $\begin{array}{c}2 \mathrm{I} .0 \\
(2.48)\end{array}$ \\
\hline & Cross $^{b}$ & $\begin{array}{c}\mathrm{I} 8.2 \\
(2.27)\end{array}$ & $\begin{array}{c}20.7 \\
(2.46)\end{array}$ & $\begin{array}{c}17.6 \\
(2.0 \mathrm{I})\end{array}$ & $\begin{array}{c}\text { II.5 } \\
\text { (I.64) }\end{array}$ & $\begin{array}{c}30.9 \\
(3.56)\end{array}$ & $\begin{array}{c}8.8 \\
(0.93)\end{array}$ & $\begin{array}{c}22.5 \\
(3.78)\end{array}$ & $\begin{array}{c}33.1 \\
(3.77)\end{array}$ & $\begin{array}{c}21.2 \\
(1.12)\end{array}$ \\
\hline & Self $^{c}$ & $\begin{array}{c}0.0 \\
(0.00)\end{array}$ & $\begin{array}{c}0.0 \\
(0.00)\end{array}$ & $\begin{array}{c}0.4 \\
(0.30)\end{array}$ & $\begin{array}{c}0.3 \\
(0.25)\end{array}$ & $\begin{array}{c}0.4 \\
(0.18)\end{array}$ & $\begin{array}{c}0 . \mathrm{I} \\
(0.12)\end{array}$ & $\begin{array}{c}0.5 \\
(0.50)\end{array}$ & $\begin{array}{c}0.0 \\
(0.00)\end{array}$ & $\begin{array}{c}0.2 \\
(0.07)\end{array}$ \\
\hline
\end{tabular}

${ }^{\mathrm{a}}$ Open is open-pollination (control). ${ }^{\mathrm{b}}$ Cross denotes the mean of cross-pollination (i.e. across TI0-T93 except self-pollination). ${ }^{\mathrm{c}}$ Self signifies selfpollination. ${ }^{\mathrm{d}}$ All nine P33-capitula pollinated with T76 were functionally male.

donors (Tab. I and 2). For instance, using PIO as a pollen donor resulted in more than twice as many immature pods per hermaphroditic capitulum on P93 compared to P92 (6I.6 versus 23.9), while for $\mathrm{P} 90$ the result was vice versa (20.3 versus 42.5 , Tab. I).

Effects of pollen doses on fruit set (excluding selfpollination) and results of the open-treatment are shown in Tab. 3. The number of capitula with at least one immature pod was not influenced by the different pollen doses while the number of pods per hermaphroditic capitulum was significantly higher in hand-pollinated capitula (cross and 'both') compared to the open-pollinated capitula. The handpollinated capitula differ in that the 'both' treatment had around 3 times more cross-pollen than the cross treatment, but only on half of the capitulum. Hence the figures can be made comparable by multiplying those for the 'both' treatment with $2 / 3:(30.8 \times 2 / 3=) 20.5$ for immature pods and $(13.5 \times 2 / 3=) 9.0$ for mature pods, which are close to the actual figures for the cross treatment on 20.4 and 9.8 for immature and mature pods, respectively (Tab. 3). However, with an increasing number of pods per capitulum the abortion rate (immature minus mature pods) also increased. For pod weight and length, the differences between pollen doses were non-significant (Tab. 3).
In one pair of trees (PI4 and P90), we found that crosspollination resulted in a similar low pod set as for selfpollination, independently of which tree was mother-tree and which was pollen donor, suggesting that these two trees were not compatible. Finally, we found another pair of trees (P76 and P92) with very few pods when P92 was the mother-tree, but only a reduced pod set when P76 was the mother-tree (Fig. I, Tab. I and 2), which suggest an incompatibility system.

\section{Comparison of self- and cross-pollinated pods}

Because the diallelic crossing experiment resulted in only two matured self-pollinated pods, we used 24 self-pollinated and 24 cross-pollinated pods originating from another experiment at the same study site, as stated above. Selfpollinated pods were significantly shorter and weighed less than cross-pollinated pods (Tab. 4). Furthermore, although not significant, the self-pollinated pods had half as many healthy seeds, significantly more aborted seeds and significantly fewer total seeds compared to the crosspollinated pods (Tab. 4). The amounts of eaten seeds and missing seeds were low, and showed no difference between selfed and outcrossed pods (Tab. 4). 
Table 2. Mean number ( $\pm \mathrm{SE}$ ) of mature pods per hermaphroditic capitulum (i.e. harvested pods) of Parkia biglobosa (incl. capitula without pods). Self-pollination (grey colour) is shown in the last row. Tree P33 was not used as a pollen donor.

\begin{tabular}{|c|c|c|c|c|c|c|c|c|c|c|}
\hline & & remale $p$ & (i.e. mo & tree) & & & & & & \\
\hline Treatm & & PIO & PI4 & P22 & P33 & P76 & P90 & P92 & P93 & Across \\
\hline & Open $^{a}$ & $\begin{array}{c}4 . \mathrm{I} \\
(\mathrm{I} .93)\end{array}$ & $\begin{array}{c}4.7 \\
(1.93)\end{array}$ & $\begin{array}{c}1.3 \\
(1.93)\end{array}$ & $\begin{array}{c}2.7 \\
(1.93)\end{array}$ & $\begin{array}{c}6.8 \\
(1.93)\end{array}$ & $\begin{array}{c}2.9 \\
(1.93)\end{array}$ & $\begin{array}{c}2.4 \\
(1.93)\end{array}$ & $\begin{array}{c}3.7 \\
(1.93)\end{array}$ & $\begin{array}{c}3.6 \\
(0.39)\end{array}$ \\
\hline & TI0 & - & $\begin{array}{c}7.3 \\
(2.36)\end{array}$ & $\begin{array}{c}16.0 \\
(5.79)\end{array}$ & $\begin{array}{c}2.0 \\
(4.09)\end{array}$ & $\begin{array}{c}\mathrm{I} 3.4 \\
\text { (I.93) }\end{array}$ & $\begin{array}{c}2.3 \\
(3.34)\end{array}$ & $\begin{array}{c}\text { I5.7 } \\
(2.19)\end{array}$ & $\begin{array}{c}23.8 \\
(2.05)\end{array}$ & $\begin{array}{c}\mathrm{I} 3.7 \\
(\mathrm{I} .84)\end{array}$ \\
\hline & TI4 & $\begin{array}{c}8.3 \\
(2.05)\end{array}$ & - & $\begin{array}{c}\text { I2.0 } \\
(4.09)\end{array}$ & $\begin{array}{c}4.8 \\
(2.36)\end{array}$ & $\begin{array}{c}\text { I5.6 } \\
(2.05)\end{array}$ & $\begin{array}{c}0.8 \\
(2.59)\end{array}$ & $\begin{array}{c}\mathrm{I} 7.5 \\
(2.36)\end{array}$ & $\begin{array}{c}10.2 \\
(2.36)\end{array}$ & $\begin{array}{c}\text { I0.I } \\
\text { (I.33) }\end{array}$ \\
\hline & T22 & $\begin{array}{c}9.2 \\
(2.36)\end{array}$ & $\begin{array}{c}5.2 \\
(2.59)\end{array}$ & - & $\begin{array}{c}7.0 \\
(2.59)\end{array}$ & $\begin{array}{c}7.3 \\
(2.19)\end{array}$ & $\begin{array}{c}4.3 \\
(2.19)\end{array}$ & $\begin{array}{c}6.8 \\
(2.59)\end{array}$ & $\begin{array}{c}\text { I7.I } \\
(2.19)\end{array}$ & $\begin{array}{c}8.4 \\
(1.04)\end{array}$ \\
\hline$\vec{~}$ & T33 & na & na & na & - & na & na & na & na & na \\
\hline 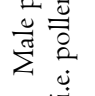 & T76 & $\begin{array}{c}7.9 \\
(2.05)\end{array}$ & $\begin{array}{c}9.0 \\
(2.36)\end{array}$ & $\begin{array}{c}8.0 \\
(2.36)\end{array}$ & $\mathrm{na}^{\mathrm{d}}$ & - & $\begin{array}{c}4.8 \\
(2.36)\end{array}$ & $\begin{array}{c}1.0 \\
(3.34)\end{array}$ & $\begin{array}{c}\mathrm{I} 8.8 \\
(2.36)\end{array}$ & $\begin{array}{c}8.9 \\
(1.09)\end{array}$ \\
\hline & T90 & $\begin{array}{c}8.0 \\
(2.36)\end{array}$ & $\begin{array}{c}0.9 \\
(2.19)\end{array}$ & $\begin{array}{c}7.0 \\
(2.59)\end{array}$ & $\begin{array}{c}5.3 \\
(2.36)\end{array}$ & $\begin{array}{c}20.0 \\
(2.05)\end{array}$ & - & $\begin{array}{c}25.3 \\
(3.34)\end{array}$ & $\begin{array}{c}6.7 \\
(3.34)\end{array}$ & $\begin{array}{c}9.9 \\
(1.54)\end{array}$ \\
\hline & T92 & $\begin{array}{c}\text { I3.5 } \\
(2.36)\end{array}$ & $\begin{array}{c}\text { II.8 } \\
(2.36)\end{array}$ & $\begin{array}{c}\text { II.0 } \\
(2.59)\end{array}$ & $\begin{array}{c}1.0 \\
(5.79)\end{array}$ & $\begin{array}{c}8.0 \\
(2.19)\end{array}$ & $\begin{array}{c}3.4 \\
(2.59)\end{array}$ & - & $\begin{array}{c}\text { I5.5 } \\
(2.89)\end{array}$ & $\begin{array}{c}\text { I0.I } \\
\text { (I.20) }\end{array}$ \\
\hline & T93 & $\begin{array}{c}\text { I3.3 } \\
(2.36)\end{array}$ & $\begin{array}{c}\text { I I.0 } \\
\text { (I.93) }\end{array}$ & $\begin{array}{c}4.2 \\
(2.59)\end{array}$ & $\begin{array}{c}\mathrm{I} .7 \\
(3.34)\end{array}$ & $\begin{array}{c}9.3 \\
(1.93)\end{array}$ & $\begin{array}{c}6.9 \\
(2.19)\end{array}$ & $\begin{array}{c}18.5 \\
(4.09)\end{array}$ & - & $\begin{array}{c}9.1 \\
(1.00)\end{array}$ \\
\hline & Cross $^{\mathrm{b}}$ & $\begin{array}{c}9.8 \\
(0.85)\end{array}$ & $\begin{array}{c}7.7 \\
(0.86)\end{array}$ & $\begin{array}{c}8.3 \\
(1.27)\end{array}$ & $\begin{array}{c}4.6 \\
(0.76)\end{array}$ & $\begin{array}{c}\mathrm{I} 2.4 \\
(\mathrm{I} .26)\end{array}$ & $\begin{array}{c}4 . \mathrm{I} \\
(0.60)\end{array}$ & $\begin{array}{c}\text { I } 4.0 \\
(2.22)\end{array}$ & $\begin{array}{c}16.6 \\
(1.65)\end{array}$ & $\begin{array}{c}10.0 \\
(0.50)\end{array}$ \\
\hline & Self $^{c}$ & $\begin{array}{c}0.0 \\
(0.00)\end{array}$ & $\begin{array}{c}0.0 \\
(0.00)\end{array}$ & $\begin{array}{c}0.3 \\
(0.19)\end{array}$ & $\begin{array}{c}0.0 \\
(0.00)\end{array}$ & $\begin{array}{c}0.3 \\
(0.16)\end{array}$ & $\begin{array}{c}0.0 \\
(0.00)\end{array}$ & $\begin{array}{c}0.0 \\
(0.00)\end{array}$ & $\begin{array}{c}0.0 \\
(0.00)\end{array}$ & $\begin{array}{c}0 . \mathrm{I} \\
(0.05)\end{array}$ \\
\hline
\end{tabular}

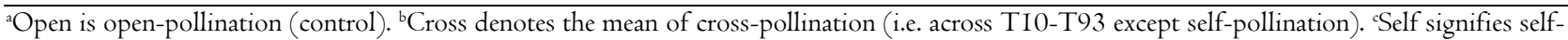
pollination. ${ }^{\mathrm{d}}$ All nine P33-capitula pollinated with T76 were functionally male.

TABLE 3. Effect of open-pollination (unknown pollen doses) and two known pollen doses on the percentage of hermaphroditic capitula with at least one immature pod, number of immature and mature pods per hermaphroditic capitulum (incl. capitula without pods), and the pod weight and length of Parkia biglobosa, including F-tests and significance levels. Except in the open-pollinated treatment, capitula were bagged until handpollination and re-bagged following pollination treatment.

\begin{tabular}{|c|c|c|c|c|c|c|c|c|}
\hline $\begin{array}{l}\text { Type of } \\
\text { pollination }\end{array}$ & $\begin{array}{l}\text { Pollen } \\
\text { doses }\end{array}$ & $\begin{array}{l}\text { No. of } \\
\text { capitula } \\
N\end{array}$ & $\begin{array}{l}\text { Capitula with } \\
\geq \mathrm{I} \mathrm{im-}^{-} \\
\text {mature pod }^{\mathrm{b}} \\
\%\end{array}$ & $\begin{array}{c}\text { No. of im- } \\
\text { mature } \\
\text { pods/capitulum }\end{array}$ & $\begin{array}{c}\text { No. of } \\
\text { mature } \\
\text { pods/capitulum }\end{array}$ & $\begin{array}{c}\text { No. } \\
\text { of } \\
\text { pods }{ }^{c}, \\
N\end{array}$ & $\begin{array}{c}\text { Pod } \\
\text { weight }^{c}, g\end{array}$ & $\begin{array}{l}\text { Pod } \\
\text { length } \\
\mathrm{cm}\end{array}$ \\
\hline Open ${ }^{d}$ & unknown & $7 \mathrm{I}$ & $100.0(\mathrm{I} .15)$ & $3.9(2.87)$ & $3.6(1.02)$ & 258 & $\begin{array}{r}\mathrm{I} 4.0 \\
(0.62)\end{array}$ & $\begin{array}{r}22.6 \\
(0.74)\end{array}$ \\
\hline Cross $^{e}$ & $1 / 3$ & 292 & 95.7 (I.I5) & $20.4(2.87)$ & $9.8(1.02)$ & 2,643 & $\begin{array}{r}\text { II.9 } \\
(0.62)\end{array}$ & $\begin{array}{r}20.7 \\
(0.74)\end{array}$ \\
\hline 'Both' & I & 40 & $98.0(\mathrm{I} .4 \mathrm{I})$ & $30.8(3.52)$ & $\mathrm{I} 3.5(\mathrm{I} .25)$ & 502 & $\begin{array}{r}12.8 \\
(0.77) \\
\end{array}$ & $\begin{array}{r}21.2 \\
(0.90) \\
\end{array}$ \\
\hline $\begin{array}{l}F(P)_{\text {Pollination }} \\
F(P)_{\text {Tree }}\end{array}$ & & & $\begin{aligned} F_{(2,12)} & =3.5 \\
& (\mathrm{~ns}) \\
F_{(7,12)}= & 0.7 \\
& (\mathrm{~ns})\end{aligned}$ & $\begin{array}{r}F_{(2,12)}=18.8 \\
F_{(7,12)}=2.3(\mathrm{~ns})\end{array}$ & $\begin{array}{r}F_{(2,12)}=20.7 \\
\\
F_{(7,12)=3.0(*)}\left(\begin{array}{l}* \\
(*)\end{array}\right.\end{array}$ & & $\begin{aligned} F_{(2,12)}= & 2.9 \\
& (\mathrm{~ns}) \\
F_{(7,12)}= & 5.6 \\
& \left({ }^{*}\right)\end{aligned}$ & $\begin{aligned} & F_{(2,12)}= I .8 \\
&(\mathrm{~ns}) \\
& F_{(7,12)}= 5.2 \\
&\left({ }^{*}\right)\end{aligned}$ \\
\hline
\end{tabular}

${ }^{a}$ Number of capitula used per type of pollination. ${ }^{b}$ Values are least squares (LS) means with the standard error (SE) in brackets of the LS estimate. Significance level: ${ }^{*}=P<0.00 \mathrm{I},{ }^{*}=P<0.0 \mathrm{I},{ }^{*}=P<0.05$, and ns $=P>0.05 .{ }^{\circ}$ Number of pods harvested. ${ }^{\mathrm{d}}$ Open was open-pollinated capitula, which were neither bagged nor hand-pollinated (control). ${ }^{\circ}$ Cross was cross-pollinated capitula with one capitulum giving pollen to three capitula (I:3 ratio). "Both' was capitula, which were self-pollinated on one half and cross-pollinated on the other half, with one capitulum giving pollen to two half capitula (I:I ratio), but only cross-pollinated pods developed. 

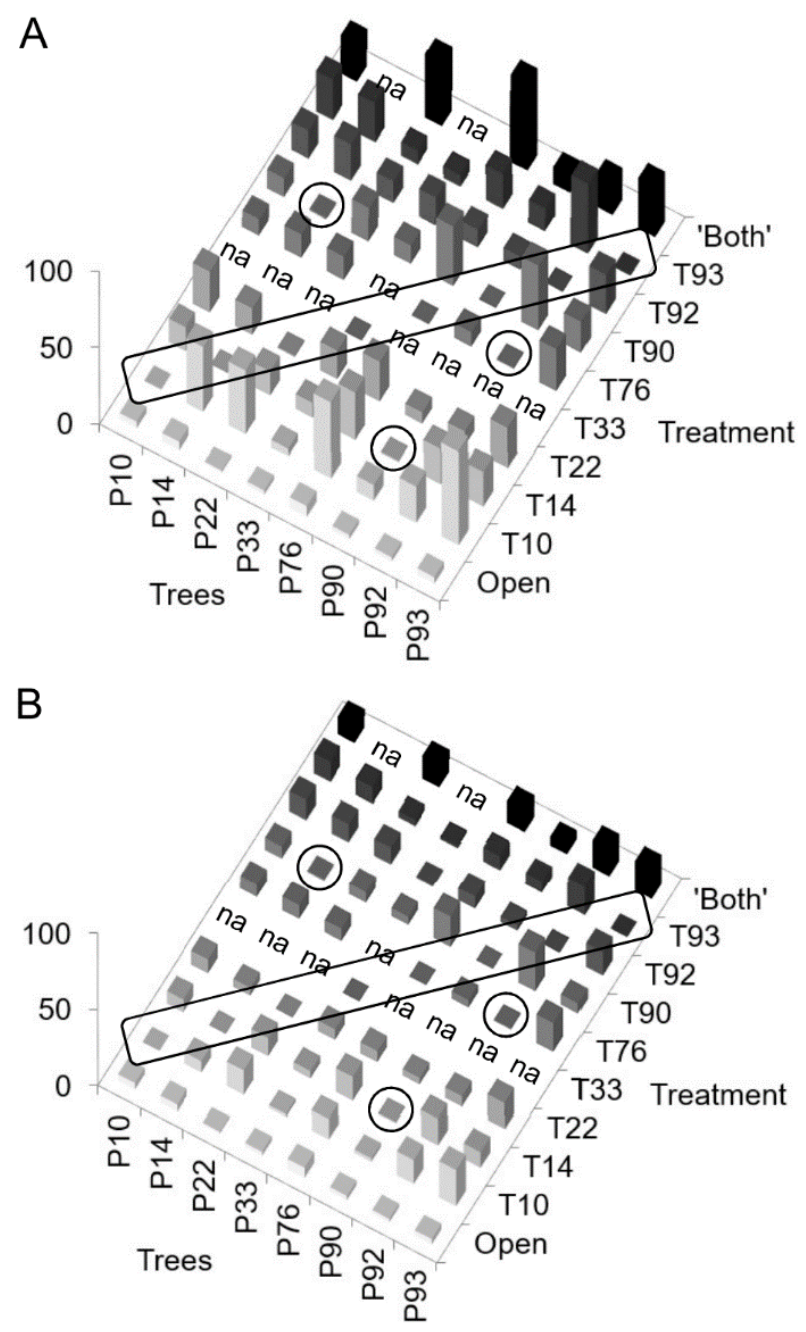

FIGURE I. Overview of the number of immature (A) and mature (B) pods per hermaphroditic capitula for Parkia biglobosa, distributed on treatments (i.e. pollen donors) and trees. The box encompasses the events of self-pollination, which all resulted in very few pods, and the circles indicate low numbers of pods resulting from cross-pollinations. 'Open' indicate open-pollination (control) and 'Both' is a treatment in which capitula were pollinated with selfpollen on one half and cross-pollen on the other half. However, 'Both' yielded exclusively outcrossed pods. Pollen donor T33 was only applied to tree P33, pollen donor T76 was applied to only functionally male capitula on tree P33 and neither tree PI4 or tree P33 had not enough capitula for the 'Both'-treatment.

Carbon \& protein contents in seeds, and sugar contents in fruit pulp

Raw, dehulled seeds from cross-pollinated seeds had slightly more carbon compared to self-pollinated seeds ( $54.3 \%$ versus $53.4 \%$ ), while percentage of protein (dry weight) was slightly lower (43.3\% versus $45.2 \%$, Tab. 4 ). The carbon content was highly dependent on seed weight $\left(F_{(1,35)}=\right.$ 12.4, $P<0.001)$ with larger seeds containing more carbon. This was not the case for amount of protein $\left(F_{(1,35)}=\right.$ I.0, $P$ $=0.3$ ), hence larger seeds contained more carbon whereas protein content was constant, regardless of seed size.
Sugar content was higher in fruit pulp for the crosspollinated pods, but only significantly so for glucose and fructose (Tab. 4). Numbers of healthy seeds and amounts of glucose, fructose and total sugars, respectively, were positively and significantly correlated (Tab. 5). No correlation was found between the amount of sucrose and number of seeds per pod (Tab. 5).

Germination and seedling growth of self- and cross-pollinated seeds

Seed weight and seedling growth was highly variable in both types of pollination (self and cross). The mean weight of cross-pollinated seeds was significantly higher than selfpollinated seeds, while germination percentage and germination speed did not differ significantly between pollination types (Tab. 4). Nine selfed and nine crosspollinated seeds germinated but died before the first measurement of seedlings, and most seedlings, which died during the trial, perished before the second measurement. From the initial 90 self-pollinated and I63 cross-pollinated seeds, significantly fewer self-pollinated seedlings (69) than cross-pollinated (I47) seedlings survived until the trial was terminated (Tab. 4). Initial fresh weights (I) days after sowing) and fresh and dry weights at harvest were significantly higher for the cross-pollinated seedlings compared to the selfpollinated ones. The shoot:root ratio was independent of the type of pollination (Tab. 4).

The growth of the seedlings is shown in Fig. 2 (A, B, and $\mathrm{C}$ ) and the final height, stem diameter and number of pinnae 222 days after sowing in Tab. 4. Means of height, diameter, and numbers of pinnae were always lower for selfpollinated seedlings compared to cross-pollinated ones, and these differences in growth increased with time (Fig. 2). Seven months after sowing (222 days), the effect of type of pollination was significant for plant height and stem diameter, but not for number of pinnae $\left(F_{(1,7)}=4.3, P=0.08\right)(\mathrm{Tab}$. 4).

\section{DISCUSSION}

Parkia biglobosa is known to be mainly outcrossing (Ouédraogo 1995; Sina 2006; Lassen et al. 2017), and this study showed that self-pollination reduced the number of pods produced, pod size, number of seeds, sugar content in pulp, seed weight, and weight of seedlings (Tab. I, 2, and 5). In addition, the diallel cross revealed that some combinations of mother-trees and pollen donors were more productive than others. The findings of variation in the success of male and female reproductive organs, i.e., an individual plant being good at either setting pods or at fathering pods on other conspecifics, has also been reported in other plant species such as the self-incompatible Trumpet creeper Campsis radicans (L.) Seem. (Bignoniaceae) (Bertin 1982) and the selfincompatible Crested dogstail grass Cynosurus cristatus L. (Poaceae) (Ennos \& Dodson 1987).

\section{Pollen limitation in Parkia biglobosa}

Controlled pollinations with different doses of crosspollen conducted in the present study yielded significantly more immature and mature fruits than in open-pollinated 
TABLE 4. Influence of self- versus cross-pollination on the fitness of various parameters of pods and seeds of Parkia biglobosa including $F$ tests, Fisher's exact tests, and their significance levels.

\begin{tabular}{|c|c|c|c|c|c|c|}
\hline & \multicolumn{4}{|c|}{ Type of pollination } & \multirow[b]{2}{*}{$F(P)_{\text {Pollination }}$} & \multirow[b]{2}{*}{$\begin{array}{l}\text { Inbreeding } \\
\text { depression }^{\mathrm{b}}, \%\end{array}$} \\
\hline & Self, $N$ & Cross, $N$ & Self ${ }^{\mathrm{a}}$ & Cross $^{a}$ & & \\
\hline Pod length, cm & 24 & 24 & I5.8 (I.I6) & $20.0($ I.I6) & $F_{(1,10)}=6.4\left(^{*}\right)$ & 21.0 \\
\hline Pod weight, g & 24 & 24 & $7.9(1.03)$ & $\mathrm{I} 2.5(\mathrm{I} .03)$ & $F_{(1,10)}=\mathrm{IO} . \mathrm{I}\left({ }^{\prime}\right)$ & 36.8 \\
\hline Husk weight, g & 24 & 24 & $4.0(0.4 \mathrm{I})$ & $5.5(0.4 \mathrm{I})$ & $F_{(1,10)}=7.5\left(^{\star}\right)$ & 27.3 \\
\hline Pulpc weight, $g$ & 22 & 24 & $2.5(0.40)$ & $4.2(0.37)$ & $F_{(1,9)}=8.7\left({ }^{*}\right)$ & 40.5 \\
\hline Seed weight, g & 24 & 24 & $1.6(0.29)$ & $2.6(0.26)$ & $\left.F_{(1,9)}=6.9{ }^{*}\right)$ & 38.5 \\
\hline \multicolumn{7}{|l|}{ Seeds per pod: } \\
\hline Healthy seeds, $n$ & 24 & 24 & $6.6(\mathrm{I} .87)$ & $\mathrm{I} 2.4(\mathrm{I} .87)$ & $F_{(1,10)}=4.8(\mathrm{~ns})$ & 46.8 \\
\hline Eaten seeds, $n$ & 24 & 24 & $\mathrm{I} .4(0.70)$ & $0.7(0.70)$ & $F_{(1,10)}=0.6(\mathrm{~ns})$ & -100.0 \\
\hline Aborted seeds ${ }^{\mathrm{d}}, n$ & 24 & 24 & $2.8(0.46)$ & I. $3(0.46)$ & $F_{(1,10)}=5.2\left({ }^{*}\right)$ & -II5.4 \\
\hline Missing seeds ${ }^{e}, n$ & 24 & 24 & I.I $(0.29)$ & $\mathrm{I} .5(0.29)$ & $F_{(1,10)}=0.9(\mathrm{~ns})$ & 26.7 \\
\hline Total seeds, $n$ & 24 & 24 & II.9 (0.99) & $15.9(0.99)$ & $F_{(1,10)}=8.1\left({ }^{*}\right)$ & 25.2 \\
\hline Moisture in seeds, \% & 24 & 24 & $3.5(0.14)$ & $3.1(0.14)$ & $F_{(1,10)}=3.3(\mathrm{~ns})$ & -12.9 \\
\hline \multicolumn{7}{|l|}{$\mathrm{C}$ and $\mathrm{N}$ in seeds, dry weight: } \\
\hline Carbon in raw seeds, $\%$ & 24 & 24 & $53.4(0.29)$ & $54.3(0.29)$ & $F_{(1,10)}=4.8(\mathrm{~ns})^{\mathrm{f}}$ & 1.6 \\
\hline Nitrogen in raw seeds, \% & 24 & 24 & $7.2(0.10)$ & $6.9(0.10)$ & $F_{(1,10)}=5.0\left(^{*}\right)$ & -4.4 \\
\hline Protein in raw seeds ${ }^{g}, \%$ & 24 & 24 & $45.2(0.60)$ & $43.3(0.60)$ & $F_{(1,10)}=5.0\left({ }^{\star *}\right)$ & -4.4 \\
\hline \multicolumn{7}{|l|}{ Sugars in fruit pulp, dry weight: } \\
\hline Sucrose $e^{c}, \%$ & 22 & 24 & $28.5(0.8 \mathrm{I})$ & $29.5(0.74)$ & $F_{(1,9)}=0.9(\mathrm{~ns})$ & 3.4 \\
\hline Glucosec,$\%$ & 22 & 24 & $3.5(0.68)$ & $5.6(0.62)$ & $F_{(1,9)}=5.6(*)$ & 37.5 \\
\hline Fructose $^{c}, \%$ & 22 & 24 & $4.2(0.5 \mathrm{I})$ & $5.9(0.47)$ & $F_{(1,9)}=5.6\left(^{*}\right)$ & 23.8 \\
\hline Total sugarc, $\%$ & 22 & 24 & $36.2(\mathrm{I} .8 \mathrm{I})$ & $41.3(1.66)$ & $F_{(1,9)}=4.3(\mathrm{~ns})$ & $\mathrm{I} 2.3$ \\
\hline \multicolumn{7}{|l|}{ Seed germination: } \\
\hline Seed weight, g & I I7 & 196 & $0.16(0.006)$ & $0.20(0.005)$ & $F_{(1,8)}=32.9\left({ }^{\prime}\right)$ & 20.0 \\
\hline Seed germination ${ }^{\mathrm{h}}, \%$ & I I7 & 196 & 76.9 & 83.2 & $P<0.2(\mathrm{~ns})$ & 7.6 \\
\hline Days to germination & 90 & 163 & $4.4(0.28)$ & $4.3(0.23)$ & $F_{(1,8)}=0.1(\mathrm{~ns})$ & -2.3 \\
\hline \multicolumn{7}{|l|}{ Seedlings: } \\
\hline Fresh weight I9 daysi, g & 88 & I6I & $0.85(0.04)$ & $1.02(0.03)$ & $F_{(1,8)}=10.2\left(^{*}\right)$ & 16.7 \\
\hline Survival 222 days ${ }^{\text {hi }}, \%$ & 90 & 163 & 76.7 & 90.2 & $P<0.005\left({ }^{(x+x}\right)$ & 15.0 \\
\hline Height 222 days ${ }^{i}, \mathrm{~cm}$ & 69 & $\mathrm{I} 47$ & $20.3(0.97)$ & $23.2(0.74)$ & $F_{(1,7)}=5.8\left({ }^{*}\right)$ & $\mathrm{I} 2.5$ \\
\hline Stem diameter 222 days ${ }^{\mathrm{i}}, \mathrm{mm}$ & 69 & $\mathrm{I} 47$ & $3.9(0.20)$ & $4.6(0.15)$ & $F_{(1,7)}=6.2\left({ }^{*}\right)$ & 15.2 \\
\hline Number of pinnae 222 days $s^{i}$ & 69 & $\mathrm{I} 47$ & $35.0(2.13)$ & $40.5(\mathrm{I} .6 \mathrm{I})$ & $F_{(1,7)}=4.3(\mathrm{~ns})$ & $\mathrm{I} 3.5$ \\
\hline Fresh weight 222 daysi , g & 69 & $\mathrm{I} 47$ & $17.0(2.03)$ & $23.4(1.53)$ & $\left.F_{(1,7)}=6.3{ }^{*}\right)$ & 27.4 \\
\hline Dry weight 222 daysi, g & 69 & $\mathrm{I} 47$ & $6.1(0.72)$ & $8.4(0.54)$ & $F_{(1,7)}=6.5\left({ }^{*}\right)$ & 27.4 \\
\hline Shoot, dry weight g & 69 & $\mathrm{I} 47$ & $2.8(0.4 \mathrm{I})$ & $4.0(0.3 \mathrm{I})$ & $F_{(1,7)}=4.9(\mathrm{~ns})$ & 30.0 \\
\hline Root, dry weight g & 69 & $\mathrm{I} 47$ & $3.3(0.48)$ & $4.5(0.37)$ & $F_{(1,7)}=3.6(\mathrm{~ns})$ & 26.7 \\
\hline Shoot:root ratio (dry weight) & 69 & $\mathrm{I} 47$ & $1.0(0.15)$ & $0.9(0.1 \mathrm{I})$ & $F_{(1,7)}=0 . \mathrm{I}(\mathrm{ns})$ & -II.I \\
\hline
\end{tabular}

capitula (Tab. 3). These results document pollen limitation of fruit set in P. biglobosa during the study year, indicating that fruit set could be increased by increasing pollen load above the natural level of pollination (but see discussion below). Freely exposed capitula attracted up to 50 honey bees foraging simultaneously per capitulum. As honey bees have been found to be good pollinators of P. biglobosa (Lassen et al. 2017), pollen limitation may be due to insufficient deposition of compatible cross-pollen compared to deposition of self- and incompatible cross-pollen. The density of P. biglobosa was relatively high (I.2 trees/ha), and seven of the eight mothertrees were separated by less than $60 \mathrm{~m}$ to the nearest $P$. biglobosa tree. However, the mother-trees were large (mean crown area $=472 \mathrm{~m}^{2}$, SD $=170$ ) with many capitula, and this profuse blooming may have increased geitonogamy of the open-pollinated capitula. Higher fruit production of controlled cross-pollination compared to controlled selfpollination and open-pollination has also been reported for other tropical tree species e.g. the Coligallo palm, Calyptrogyne ghiesbreghtiana H. Wendl. (Cunningham 1996) (Arecaceae) and five species of neotropical Inga trees (Koptur 1984) (Fabaceae), where it has been linked to limitation of compatible pollen of self- and open-pollinations. 
TABLE 5. Correlation between number of seeds per pod and amount of sugar (sucrose, glucose, and fructose) in pulp for 46 pods ( 22 selfpollinated and 24 cross-pollinated) of Parkia biglobosa illustrated by Pearson correlation coefficients and significance levels.

\begin{tabular}{|c|c|c|c|c|}
\hline & Sucrose & Glucose & Fructose & Total sugars \\
\hline No. of healthy seeds & 0.19 (ns) & $0.48(x)$ & $0.38\left({ }^{x}\right)$ & $0.48\left({ }^{\prime}\right)$ \\
\hline No. of aborted seeds & 0.08 (ns) & $-0.48\left({ }^{(x+y}\right)$ & $-0.42(x)$ & -0.28 (ns) \\
\hline No. of total seeds & 0.15 (ns) & 0.26 (ns) & 0.19 (ns) & $0.3 \mathrm{I}\left({ }^{*}\right)$ \\
\hline
\end{tabular}
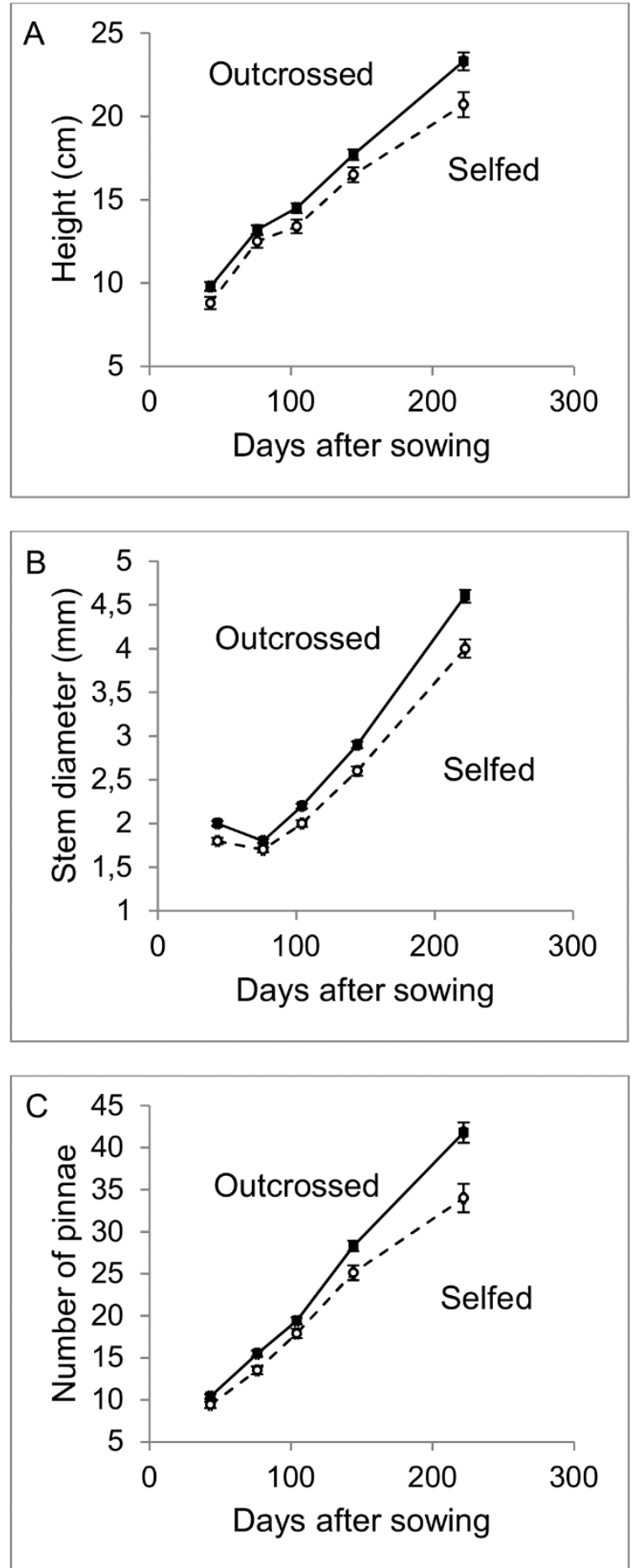

FIGURE 2. Growth of seedlings of Parkia biglobosa originating from 69 self-pollinated and I47 cross-pollinated seeds, showing the temporal development (days after sowing) of A) mean height, B) mean stem diameter, and C) mean number of pinnae. Error bars indicate \pm I standard error of the mean. Only seedlings, which survived until harvest at 222 days after sowing are included.

Although half of the immature pods were aborted in controlled cross-pollinations, pollen dose was highly important for number of mature pods in Parkia biglobosa. The converting calculations between treatments with different pollen doses ('cross' and 'both') proposed a linear relationship between pollen dose and fruit set, suggesting that even more pods could have been initiated and matured, if the high dose of the cross-pollen in the 'both'-treatment $(\mathrm{I}: \mathrm{I})$ had been applied to the whole capitulum, and not only to half of it, or if the pollen dose had been even higher (e.g., 3:I). Most likely, the increased abortion of pods (i.e., immature pods minus mature pods) with higher pollen doses were due to lack of resources, suggesting that there is an upper limit for the number of produced pods per capitulum. However, we found no differences in pod weight or pod length between pods from open-, cross- or 'both'-treatments. The experiment had some limitations, and hence we cannot conclude whether the trees were truly pollen limited. First, the experiment lasted only one night at each tree; second, only a part of the blooming capitula per tree was included in the experiment; third, the experiment was only performed in one season. It is possible that the increased fruit set of hand-pollinated capitula came at the cost of open-pollinated capitula within the same tree (Obeso 2002). Nevertheless, some plant species show pollen limitation both on a whole plant level and in subsequent years (Ashman et al. 2004). More detailed hand-pollination experiments are needed to test whether a higher fruit production can be obtained in P. biglobosa by supplying cross-pollen night after night and year after year.

In the current study, a cross-pollinated capitulum was pollinated with only one cross-pollen donor, and hence the pod abortion was not due to selection between pollen donors, as has sometimes been suggested when explaining high rates of abortion (Bookman 1984). These patterns suggest a general lack of maternal resources to mature all or most of the initiated cross-pollinated pods.

\section{Self-incompatibility in Parkia biglobosa}

Self-incompatibility of P. biglobosa, as suggested by our study, is supported by other studies: Using controlled self- and 
cross-pollination ( $N=$ I5 trees), Ouédraogo (I995) concluded that $P$. biglobosa is largely a self-incompatible species: self-pollination was possible, but outcrossing was more successful. Likewise, Sina (2006) found high values of multi-locus outcrossing ( $N=238$ trees), also consistent with partial self-incompatibility. Parkia is a pantropical genus of around 35 species, of which most are believed to be batpollinated and the rest insect-pollinated (Hopkins 1998). The breeding system of most Parkia species has not been investigated (Bumrungsri et al. 2008), but their high pollen:ovule ratios are in the range characteristic of outcrossing (Cruden 1977; Hopkins 1984). Piechowski (2007) has tested Parkia pendula in Brazil for selfing, and as no pods were produced in spontaneous or controlled selfpollinations, he concluded that this species was selfincompatible. Furthermore, a study of two Asian species of Parkia, P. speciosa and P. timoriana, involving spontaneous (i.e. bagged capitula) and controlled self-pollination treatments, suggested that both species were self-incompatible (Bumrungsri et al. 2008). Finally, our finding of two crossincompatible tree pairs (PI4 \& P90, and P76 \& P92) fit with the self-incompatibility being controlled by a few specific loci (de Nettancourt 1977; Seavey and Bawa I986).

In spite of the high pollen dose in the 'both'treatment, no self-pollinated flowers developed into pods in this treatment. Since only one polyad pollinates one flower in P. biglobosa (Lassen et al. 20I4), competition and selection between pollen donors is likely to take place between flowers rather than within flowers (Bawa \& Buckley 1989). Pod set after self-pollination of the entire capitulum was rare. The 24 selfed pods contained significantly more aborted seeds and fewer total seeds, perhaps due to late acting selfincompatibility and/or early acting inbreeding depression. The 'missing' seeds were thought to be seeds that aborted very early, leaving only the empty cavity in the pulp, but we found few cavities per pod, and no differences between types of pollination.

\section{Inbreeding depression in Parkia biglobosa}

Initial seedling growth has been shown to depend on seed size, possibly due to the size of the cotyledons (Blackman 1919; Howe \& Richter 1982; Boot 1996). Considering the correlation between carbon content and seed weight, and the higher seed weight of cross-pollinated seeds, we hypothesise that the nutritional differences between selfed and outcrossed seeds were due to relatively larger cotyledons in the crosspollinated seeds. Because the differences in growth between self- and cross-pollinated seedlings increased with time in this study, we expect that the self-pollinated seedlings suffered from inbreeding depression. Few cases of inbreeding depression in early germination stages have been documented in other plant species while inbreeding depression at later life stages ('seed production of parent' and 'growth and reproduction') has more often been reported (Husband \& Schemske I996; Hardner \& Potts I995). A study by Mašková and Herben (2018) showed that larger-seeded species consistently had lower root:shoot ratios, explained by an advantage of faster development of shoots in asymmetric above-ground competition. We found no difference between shoot:root ratios of selfed and outcrossed seedlings, perhaps due to lack of competition in the greenhouse. In the present study, the test of germination and growth took place under presumably optimal growth conditions (available water, light, nutrition and no competition), but the survival of seedlings was significantly lower for self-pollinated seeds. Walters \& Reich (2000) observed that for ten tree species survival of seedlings in low light and/or low levels of $\mathrm{N}$ increased with seed weight. Therefore, it is likely that under natural conditions, inbreeding depression may have been more evident.

We expect that increased selfing in natural populations of P. biglobosa will negatively affect propagation by seeds, resulting in decreasing densities of adult trees in the future.

\section{Quality of seeds and pod pulp from self- and cross- pollinated capitula}

Pollination has been shown to impact the quality of fruits in different species (IPBES 2016). Because seeds and pulp from $P$. biglobosa are important food resources consumed by people and animals, it is highly relevant to understand the impact of self- versus cross-pollination on fruit and seed quality.

The content of protein in raw P. biglobosa seeds without testa (dry weight) of $43 \%-45 \%$ (for outcrossed and selfed seeds, respectively) is similar to $43 \%$ found by one study (Ekpenyong et al. 1977), but much higher than reported by other studies: 27\% (Esenwah \& Ikenebomeh 2008), 30\% (syn. Parkia filicoidea Welw.) (Fetuga et al. 1974) and 34\% (Ijarotimi \& Keshinro 2012). We found that self-pollinated seeds were more protein-rich but weighed less than crosspollinated seeds. Hence, the increase in protein content can probably be explained by a simple concentration effect as found for various species grown under stress (Wang \& Frei 20II). Inverse relationships of protein content and starch content of grains and yield, respectively, have been documented inmaize hybrids (Zea mays subsp. mays L.) (Poaceae) (Idikut et al. 2009). Likewise, other studies of maize have found significantly higher protein content in selfpollinated kernels and significantly higher starch content in cross-pollinated kernels (Letchworth \& Lambert 1998; Sulewska et al. 2014). Total seed protein produced by selfpollinated pods was much lower than for crossed pods, as selfpollinated pods contained much fewer healthy seeds (Tab. 4)

The positive correlation between seed number per pod and sugar content in pulp observed in the current study was also found in a similar study of P. biglobosa in The Gambia (Lassen et al. 2012). However, the percentages of sugars (dry weight) were much higher in the fruit pulp from The Gambia compared with the pulp from Burkina Faso (total sugar: 60\% versus $36-41 \%$ ) (Lassen et al. 20I2). In the literature, carbohydrate content (dry weight) in fruit pulp of $P$. biglobosa is reported to be from around $40 \%$ in Nigeria (Nadro \& Umaru 2004) to around 85\% in Mali (Nordeide et al. 1996). The positive correlation between number of healthy seeds and total amount of sugar in the pulp in the current study may be due to seeds acting as sinks during pod development, attracting nutrients to their own growth and to that of the surrounding pod (Stephenson I98I; Lee I988; Marcelis \& Hofman-Eijer, I997). Similarly, Valantin- 
Morison et al. (2006) found a less-pronounced sweetness of the flesh in fruits with few filled seeds compared to fruits with a normal number of filled seeds in cantaloupe melon (Cucumis melo L.). In self-compatible, sweet orange (Citrus sinensis var. Red Junar) (Rutaceae), Partap (2000) found a higher number of seeds and more juice with a higher sugar content after honey bee pollination compared to windpollination.

Overall, our results suggest that fruit production, nutritional value of $P$. biglobosa pulp and seeds, and the fitness of seedlings, will decrease with increased levels of selfpollinations and affect the rural human populations negatively. We propose more research into how to increase the regeneration (natural or planted) of P. biglobosa. Our results could also be expanded by testing combinations of some of the acknowledged plus-trees (i.e. the superior trees) of $P$. biglobosa and by grafting the best combinations together, making it easier for the pollinators to bring about more crosspollination with highly compatible pollen.

\section{ACKNOWLEDGEMENTS}

We thank the staff of the Centre National de Semences Forestières (CNSF) for their cooperative spirit. Thanks to Alassane Ouédraogo, Madi Tiemtoré, and Philbert Zoungrana for field assistance and to the farmers in Pinyiri for allowing us to use their trees. We also thank Sofie Fiona Hansen, Ruth Bruus Jakobsen, and Annalise Metz for measuring the pods; head laboratory technician Lene Korsholm Jørgensen from the Department of Plant and Environmental Sciences (UCPH) for analysing the content of carbohydrates in the fruit pulp of P. biglobosa; laboratory coordinator Preben Frederiksen from the Department of Geosciences and Natural Resources (UCPH) for analysing the content of carbon and nitrogen in the seeds of P. biglobosa; gardener Kurt Dahl and greenhouse supervisor Theodor Emil Bolsterli for taking good care of the P. biglobosa seedlings in the greenhouse (UCPH). The present paper is part of a $\mathrm{PhD}$ study financed by the Danish International Development Agency (Danida (FFU), research project no. I0-I06LIFE).

\section{REFERENCES}

Abrol DP (2012) Pollination biology. Biodiversity conservation and agricultural production. Springer, New York, USA.

Aizen MA, Harder LD (2007) Expanding the limits of the pollenlimitation concept: Effects of pollen quantity and quality. Ecology $88: 27 \mathrm{I}-28 \mathrm{I}$

AOAC (Association of Official Analytical Chemists) (1990) Official methods of Analysis of the AOAC. (No. 954.0I). Volume I. Association of Official Analytical Chemists Inc., Arlington, USA.

Ashman T-L, Knight TM, Steets JA, Amarasekare P, Burd M, Campbell DR, Dudash MR, Johnston MO, Mazer SJ, Mitchell RJ, Morgan MT, Wilson WG (2004) Pollen limitation of plant reproduction: Ecological and evolutionary causes and consequences. Ecology 85:2408-242I.

Baker HG, Harris BJ (1957) The pollination of Parkia by bats and its attendant evolutionary problems. Evolution I I:449-460.

Bawa KS, Buckley DP (I989) Seed: ovule ratios, selective seed abortion and mating systems in Leguminosae. In: Stirton $\mathrm{CH}$, Zarucchi JL (eds.) Advances in legume biology. Monographs of systematic botany of the Missouri Botanical Garden No. 29. Missouri Botanical Garden, St. Louis, USA, pp 243-262.
Bawa KS, Perry DR, Beach JH (1985) Reproductive biology of tropical lowland rain forest trees. I. Sexual systems and incompatibility mechanisms. American Journal of Botany 72:33I345.

Bertin RI (1982) Paternity and fruit production in trumpet creeper (Campsis radicans). American Naturalist I 19:694-709.

Blackman VH (1919) The compound interest law and plant growth. Annals of Botany 33:353-360.

Bookman SS (1984) Evidence for selective fruit production in Asclepias. Evolution 38:72-86.

Boot RGA (1996) The significance of seedling size and growth rate of tropical rain forest tree seedlings for regeneration in canopy openings. In: Swaine MD (ed.) The ecology of tropical forest tree seedlings. UNESCO, Paris, France, pp 267-283.

Bumrungsri S, Harbit A, Benzie C, Carmouche K, Sridith K, Racey P (2008) The pollination ecology of two species of Parkia (Mimosaceae) in southern Thailand. Journal of Tropical Ecology 24:467-475.

Cruden RW (1977) Pollen-Ovule ratios: A conservative indicator of breeding systems in flowering plants. Evolution 3I:32-46.

Cunningham SA (1996) Pollen supply limits fruit initiation by a rain forest understorey palm. Journal of Ecology 84:185-194.

de Nettancourt D (1977) Incompatibility in angiosperms. SpringerVerlag, New York, USA.

Ekpenyong TE, Fetuga BL, Oyenuga VA (1977) Fortification of maize flour-based diets with blends of cashewnut meal, African locust bean meal and sesame oil meal. Journal of the Science of Food and Agriculture 28:710-716.

Ennos RA, Dodson RK (1987) Pollen success, functional gender and assortative mating in an experimental plant population. Heredity 58:119-126.

Esenwah CN, Ikenebomeh MJ (2008) Processing effects on the nutritional and anti-nutritional contents of African locust bean (Parkia biglobosa Benth.) seed. Pakistan Journal of Nutrition 7:214-217.

Etejere EO, Fawole MO, Sani A (1982) Studies on the seed germination of Parkia clapertoniana. Turrialba 32:18I-I85.

Ezeagu IE, Petzke JK, Metges CC, Akinsoyinu AO, Ologhobo AD (2002) Seed protein contents and nitrogen-to-protein conversion factors for some uncultivated tropical plant seeds. Food Chemistry 78:105-109.

Fetuga BL, Babatunde GM, Oyenuga VA (1974) Protein quality of some unusual protein foodstuffs. Studies on the African locustbean seed (Parkia filicoidea Welw.). British Journal of Nutrition 32:27-36.

Funk C, Rowland J, Adoum A, Eilerts G, White L (2012). A climate trend analysis of Burkina Faso, U.S. Geological Survey, South Dakota, USA.

Gaisberger H, Kindt R, Loo J, Schmidt M, Bognounou F, Da SS, Diallo OB, Ganaba S, Gnoumou A, Lompo D, Lykke AM, Mbayngone E, Nacoulma BMI, Ouedraogo M, Ouédraogo O, Parkouda C, Porembski S, Savadogo P, Thiombiano A, Zerbo G, Vinceti B (2017) Spatially explicit multi-threat assessment of food tree species in Burkina Faso: A fine-scale approach. PLoS ONE I2:e0I 84457.

Goulson D, Nicholls B, Botias C, Rotheray E (2015) Bee declines driven by combined stress from parasites, pesticides and lack of flowers. Science 347:1255957.

Hall JB, Tomlinson HF, Oni PI, Buchy M, Aebischer DP (I997) Parkia biglobosa: a monograph. School of Agricultural and Forest Sciences Publications Number 9, University of Wales, Bangor, UK. 
Hardner CM, Potts BM (1995). Inbreeding depression and changes in variation after selfing in Eucalyptus globulus ssp. globulus. Silvae Genetica 44:46-54.

Hinata K, Watanabe M, Toriyama K, Isogai A (1993) A review of recent studies on homomorphic self-incompatibility. International Review of Cytology I43:257-296.

Hopkins HC (198I) Taxonomy and reproductive biology of, and evolution in the bat-pollinated genus Parkia. PhD thesis, Oxford University, St. Hilda's College, UK.

Hopkins HC (1983) The taxonomy, reproductive biology and economic potential of Parkia (Leguminosae: Mimosoideae) in Africa and Madagascar. Botanical Journal of the Linnean Society 87:135-I67.

Hopkins HC (1984) Floral biology and pollination ecology of the neotropical species of Parkia. Journal of Ecology 72:I-23.

Hopkins HCF (1998) Bat pollination and taxonomy in Parkia (Leguminosae: Mimosoideae). In: Hopkins HCF, Huxley CR, Pannell CM, White F (eds.) The biological monograph. The importance of field studies and functional syndromes for taxonomy and evolution of tropical plants. The Royal Botanical Gardens, Kew, UK, pp 3I-55.

Hopping ME (1976) Effect of exogenous auxins, gibberellins, and cytokinins on fruit development in Chinese gooseberry (Actinidia chinensis Planch.). New Zealand Journal of Botany I4:69-75.

Howe HF, Richter WM (1982) Effects of seed size on seedling size in Virola surinamensis; a within and between tree analysis. Oecologia 53:347-35I.

Husband BC, Schemske DW (1996) Evolution of the magnitude and timing of inbreeding depression in plants. Evolution 50:54-70.

Idikut L, Atalay AI, Kara SN, Kamalak A (2009) Effect of hybrid on starch, protein and yields of maize grain. Journal of Animal and Veterinary Advances 8:1945-1947.

Ijarotimi OS, Keshinro OO (2012) Comparison between the amino acid, fatty acid, mineral and nutritional quality of raw, germinated and fermented African locust bean (Parkia biglobosa) flour. Acta Scientiarum Polonorum Technologia Alimentaria II:I5I-I65.

IPBES (2016) The assessment report on pollinators, pollination and food production of the Intergovernmental Science-Policy Platform on Biodivversity and Ecosystem Services. Potts SG, ImperatrizFonseca VL, Ngo HT (eds). Secretary of the Intergovernmental Science-Policy Platform on Biodivversity and Ecosystem Services, Bonn, Germany.

Kennedy CM, Lonsdorf E, Neel MC, Williams NM, Ricketts TH, Winfree R, Bommarco R, Brittain C, Burley AL, Cariveau D, Carvalheiro LG, Chacoff NP, Cunningham SA, Danforth BN, Dudenhöffer J-H, Elle E, Gaines HR, Garibaldi LA, Gratton C, Holzschuh A, Isaacs R, Javorek SK, Jha S, Klein AM, Krewenka K, Mandelik Y, Mayfield MM, Morandin L, Neame LA, Otieno M, Park M, Potts SG, Rundlöf M, Saez A, Steffan-Dewenter I, Taki H, Felipe Viana B, Westphal C, Wilson JK, Greenleaf SS, Kremen C (2013) A global quantitative synthesis of local and landscape effects on wild bee pollinators in agroecosystems. Ecology Letters I6:584-599.

Knight TM, Steets JA, Vamosi JC, Mazer SJ, Burd M, Campbell DR, Dudash MR, Johnston MO, Mitchell RJ, Ashman T-L (2005) Pollen limitation of plant reproduction: Pattern and process. Annual Review of Ecology, Evolution and Systematics 36:467-497.

Koptur S (1984) Outcrossing and pollinator limitation of fruit-set breeding systems of neotropical Inga trees (Fabaceae, Mimosoideae). Evolution 38:I I30-I I43.

Krotz L, Giazzi G (2014) Technical comparison of the Thermo Scientific FLASH 2000 Nitrogen/Protein Analyzer with the traditional Kjeldahl method Technical Note 42215. Thermo Fisher Scientific, Milan, Italy.

Lassen KM, Kjær ED, Ouédraogo M, Nielsen LR (20I4) Microsatellite primers for Parkia biglobosa (Fabaceae: Mimosoideae) reveal that a single plant sires all seeds per pod. Applications in Plant Sciences 2:1400024.

Lassen KM, Ouédraogo M, Dupont YL, Kjær ED, Nielsen LR (2017) Honey bees ensure the pollination of Parkia biglobosa in absence of bats. Journal of Pollination Ecology 20:22-34.

Lassen KM, Ræbild A, Hansen H, Brødsgaard CJ, Eriksen EN (2012) Bats and bees are pollinating Parkia biglobosa in The Gambia. Agroforestry Systems 85:465-475.

Lee TD (1988) Patterns of fruit and seed production. In: Lovett Doust J, Lovett Doust L (eds.) Plant reproductive ecology. Patterns and strategies. Oxford University Press, New York, USA, pp I79202.

Letchworth MB, Lambert RJ (1998) Pollen parent effects on oil, protein, and starch concentration in maize kernels. Crop Science 38:363-367.

Liu FL, Jensen CR, Andersen MN (2004) Drought stress effect on carbohydrate concentration in soybean leaves and pods during early reproductive development: its implication in altering pod set. Field Crops Research 86:I-I3.

Lykke AM, Mertz O, Ganaba S (2002) Food consumption in rural Burkina Faso. Ecology of Food and Nutrition 4I:I I9-I53

Maranz S (2009) Tree mortality in the African Sahel indicates an anthropogenic ecosystem displaced by climate change. Journal of Biogeography 36:II8I-II93.

Marcelis LFM, Hofman-Eijer LRB (1997) Effects of seed number on competition and dominance among fruits in Capsicum annuum L. Annals of Botany 79:687-693.

Mašková T, Herben T (2018) Root:shoot ratio in developing seedlings: How seedlings change their allocation in response to seed mass and ambient nutrient supply. Ecology and Evolution 2018;00:I-8. https//doi.org/I0.I002/ece3.4238.

Météo (2015) Pluviometrie mensuelle $(\mathrm{mm})$ dans Guilongou (Ziniare) et Pô 20I0-20I2 et temperature mensuelle $\left({ }^{\circ} \mathrm{C}\right)$ dans Ouagadougou Aéroport et Pô 2011-2012, Direction Générale de la Météorologie du Burkina, Ouagadougou, Burkina Faso.

Nadro M, Umaru H (2004) Comparative chemical evaluation of locust bean (Parkia biglobosa) fruit pulp harvested during the dry and wet season. Nigerian Journal of Biotechnology I5:42-47.

Nordeide MB, Hatloy A, Folling M, Lied E, Oshaug A (I996) Nutrient composition and nutritional importance of green leaves and wild food resources in an agricultural district, Koutiala, in Southern Mali. International Journal of Food Sciences and Nutrition 47:455-468.

Nyadanu D, Adu Amoah R, Obeng B, Kwarteng AO, Akromah R, Aboagye LM, Adu-Dapaah H (2017) Ethnobotany and analysis of food components of African locust bean (Parkia biglobosa (Jacq.) Benth.) in the transitional zone of Ghana: implications for domestication, conservation and breeding of improved varieties. Genetic Resources and Crop Evolution 64:I23I-I240,

Obeso JR (2002) The costs of reproduction in plants. New Phytologist I55:32I-348.

Ollerton J, Winfree R, Tarrant S (20I I) How many flowering plants are pollinated by animals? Oikos I20:32I-326.

Osonubi O, Fasehun FE (1987) Adaptations to soil drying in woody seedlings of African locust bean, (Parkia biglobosa (Jacq.) Benth.) Tree Physiology 3:32I-329.

Ouédraogo AS (1995) Parkia biglobosa (Leguminosae) in West Africa; biosystematics and improvement, Landbouwuniversiteit 
Wageningen (Wageningen Agricultural University), Wageningen, The Netherlands.

Partap U (2000) Foraging behaviour of Apis cerana on sweet orange (Citrus sinensis var Red Junar) and its impact on fruit production. In: Asian bees and beekeeping. Progress of research and development. Proceedings of the 4th Asian Apicultural Association, Kathmandu, Nepal, pp 174-177.

Piechowski D (2007) Reproductive ecology, seedling performance, and population structure of Parkia pendula in an Atlantic forest fragment in Northeastern Brazil, Universität Ulm, Köln, Germany.

Ræbild A, Hansen UB, Kambou S (2012) Regeneration of Vitellaria paradoxa and Parkia biglobosa in a parkland in Southern Burkina Faso. Agroforestry Systems 85:443-453.

Roldán Serrano A, Guerra-Sanz JM (2006) Quality fruit improvement in sweet pepper culture by bumblebee pollination. Scientia Horticulturae I I0:I60-I66.

Sanfo JB (20I2) Apport de la Direction Générale de la Météorologie dans le processus d'information sur l'eau I3ème sommet de l'information sur l'eau, II-I3 April 2012, Ouagadougou, Burkina Faso.

SAS Institute (20II) The SAS system for Windows. Release 9.4, Cary, North Carolina, USA.

Seavey SR, Bawa KS (1986) Late-acting self-incompatibility in angiosperms. Botanical Review 52:195-219.

Sina S (2006) Reproduction et diversité génétique chez Parkia biglobosa (Jacq.) G.Don, Wageningen University, Wageningen, the Netherlands.
Stephenson AG (198I) Flower and fruit abortion: Proximate causes and ultimate functions. Annual Review of Ecology and Systematics I2:253-279.

Sulewska H, Adamczyk J, Cygert H, Rogacki J, Szymanska G, Smiatacz K, Panasiewicz K, Tomaszyk K (20I4) A comparison of controlled self-pollination and open pollination results based on maize grain quality. Spanish Journal of Agricultural Research I2:492-500.

Uwaegbute AC (1996) African locust bean (Parkia filicoidea Welw.). In: Nwokolo E, Smartt J (eds.) Food and feed from legumes and oilseeds. Chapman \& Hall, London, United Kingdom, pp 124-129.

Valantin-Morison M, Vaissiere BE, Gary C, Robin P (2006) Source-sink balance affects reproductive development and fruit quality in cantaloupe melon (Cucumis melo L.). Journal of Horticultural Science and Biotechnology 8I:I05-I I7.

Walters MB, Reich PB (2000) Seed size, nitrogen supply, and growth rate affect tree seedling survival in deep shade. Ecology 8I:I887-I90I.

Wang Y, Frei M (20II) Stressed food - The impact of abiotic environmental stresses on crop quality. Agriculture, Ecosystems \& Environment I4I:27I-286.

Ward M, Dick CW, Gribel R, Lowe AJ (2005) To self, or not to self... a review of outcrossing and pollen-mediated gene flow in neotropical trees. Heredity 95:246-254.

Yeoh HH, Wee YC (1994) Leaf protein contents and nitrogen-toprotein conversion factors for 90 plant species. Food Chemistry 49:245-250. 